\title{
Complementary DNA for the Folate Binding Protein Correctly Predicts Anchoring to the Membrane by Glycosyl-Phosphatidylinositol
}

\author{
Stephen W. Lacey, ${ }^{\star}$ Joann M. Sanders, ${ }^{\ddagger}$ Karen G. Rothberg, ${ }^{\ddagger}$ Richard G. W. Anderson, ${ }^{5}$ and Barton A. Kamen ${ }^{\ddagger}$ \\ Departments of ${ }^{*}$ Internal Medicine, ${ }^{\ddagger}$ Pediatrics, and ${ }^{\S}$ Cell Biology and Anatomy, University of Texas Southwestern Medical Center, \\ Dallas, Texas 75235
}

\begin{abstract}
Membrane bound and soluble forms of a high-affinity folate binding protein have been found in kidney, placenta, serum, milk, and in several cell lines. The two forms have similar binding characteristics for folates, are immunologically crossreactive and based upon limited amino acid sequence data, are nearly identical. Based upon pulse-chase experiments, a precursor-product relationship has been suggested. The membrane form has been shown to mediate the transport of folate in cells grown in physiological concentrations of folate. A function for the soluble form has not yet been identified. We constructed a cDNA library from a human carcinoma cell line, Caco-2, which expresses the membrane form abundantly. The library was screened and a near full-length cDNA for the folate binder was isolated. Transfection of COS cells with the cDNA inserted in an expression vector resulted in marked overexpression of a membrane-associated folate binder as assessed by direct binding of radiolabeled folate and by indirect immunofluorescence. The deduced amino acid sequence is not consistent with a typical membrane spanning domain but rather with a signal for anchoring via a glycosyl-phosphatidylinositol linkage. Release of the binder with a phosphatidylinositol-specific phospholipase $\mathbf{C}$ strongly supports this hypothesis.
\end{abstract}

\section{Introduction}

Folate binding protein $(\mathrm{FBP})^{1}$ is the designation given for a protein that has a high affinity for folic acid as well as a number of reduced folic acid derivatives. Originally purified as a soluble protein from bovine milk (1-3), it has been found in human serum $(4,5)$, human and goat milk $(6,7)$, human urine (8), and granulocyte lysates from patients with chronic granulocytic leukemia $(9,10)$. A particulate form of this protein, which can only be solubilized with detergents, has been purified from human milk (11), kidney (12), placenta (13), and

Address reprint requests to Dr. Stephen W. Lacey, Department of Internal Medicine, University of Texas Southwestern Medical Center, 5323 Harry Hines Boulevard, Dallas, TX 75235.

Received for publication 20 March 1989.

1. Abbreviations used in this paper: FBP, folate binding protein; M, membrane; PI-PLC, phosphatidylinositol phospholipase C; S, soluble.

J. Clin. Invest.

(c) The American Society for Clinical Investigation, Inc.

0021-9738/89/08/0715/06 \$2.00

Volume 84, August 1989, 715-720 cultured KB cells (14). The two forms of the protein are referred to as the soluble folate binding protein (S-FBP) and membrane folate binding protein (M-FBP) respectively. The S-FBP and M-FBP are immunologically similar proteins (15) and both have similar folate binding characteristics.

The exact function of the S-FBP is not known. Rubinoff and co-workers have shown that goat milk S-FBP is a sialoglycoprotein and that the hepatic clearance of $\left[{ }^{125} \mathrm{I}\right]-\mathrm{S}-\mathrm{FBP}$ after injection into the blood stream of goats and rats is inhibited by desialyzed fetuin but not fetuin, which suggests a role for this protein in the folate enterohepatic cycle (16). Tani et al. (17), found that bovine milk S-FBP slowed the absorption of $\left[{ }^{14} \mathrm{C}\right]$ folic acid from the rat gastrointestinal tract in situ. In addition, Tani and Iwai (18) showed that the S-FBP completely inhibited the incorporation of $\left[{ }^{3} \mathrm{H}\right]$ folic acid by Lactobacillus casei, a common intestinal bacterium.

The M-FBP, by contrast, appears to function as a surface membrane receptor that mediates delivery of 5-methyltetrahydrofolate to the interior of cells (19). Recent studies (20) suggest that when 5-methyltetrahydrofolate binds to externally oriented receptors on the surface of MA104 cells, it is carried into an acidic vesicular compartment where it dissociates from the receptor before being translocated across the membrane into the cytoplasm. The unoccupied receptor then returns to the cell surface to participate in another round of uptake.

Kane and co-workers (15) found that in cultured KB cells there appears to be a precursor-product relationship between the M-FBP and the S-FBP. They also found that the KB cell S-FBP had a similar molecular weight and amino acid composition to the milk S-FBP but that the M-FBP contained an additional 75-100 amino acid residues and was 7,000-15,000 greater in molecular weight. On the other hand, Luhrs et al. (21) reported that the two FBPs had similar molecular weights and amino acid composition but differed in that the M-FBP had multiple fatty acid residues covalently linked by both amide and ester bonds.

We have cloned and expressed a near full length cDNA for M-FBP. Sequence analysis predicts that the M-FBP is anchored by a glycosyl-phosphatidylinositol (GPI) moiety, which we have confirmed by showing that M-FBP is released from MA104 cell membranes with PI-PLC.

\section{Methods}

Reagents, enzymes, and radionucleotides. Restriction enzymes, Klenow fragment of DNA polymerase I, $T_{4}$ DNA kinase, $T_{4}$ DNA ligase, and $T_{4}$ DNA polymerase were obtained from New England Biolabs (Boston, MA) and Boehringer-Mannheim Biochemicals (Indianapolis, IN). M-MLV reverse transcriptase (8025SA) was obtained 
from Bethesda Research Laboratories (Bethesda, MD). pGEM4Z plasmid, protoclone $\lambda \mathrm{gt} 11$ systems and the pCMV2 plasmid were obtained through Promega Biotec (Madison, WI), Stratagene Corp. (San Diego, CA), and the kind gift of David W. Russell (Fig. 1) (University of Texas-Southwestern, Dallas, TX) (22) respectively. Radionucleotides ${ }^{32} \mathrm{P} \gamma$-ATP $(3,000 \mathrm{Ci} / \mathrm{mmol}),{ }^{32} \mathrm{P} \alpha$-dATP $(800 \mathrm{Ci} / \mathrm{mmol}),{ }^{32} \mathrm{P} \alpha$ dCTP $(800 \mathrm{Ci} / \mathrm{mmol})$ were obtained from New England Nuclear (Boston, MA). Oligo-dT cellulose type 7 and oligo-dt $\mathrm{dt}_{12-18}$ were from Pharmacia Fine Chemicals (Piscataway, NJ), nitrocellulose membranes were from Millipore Corp. (HATF 082 025; Bedford, MA) and Nytran membranes $(01010)$ from Schleicher \& Schuell (Keene, NH). $\left[{ }^{3} \mathrm{H}\right]$ Folic acid $(20-40 \mathrm{Ci} / \mathrm{mmol}, \mathrm{MT} 783)$ was obtained from Moravek Biochemicals (City of Industry, CA) and 5-methyl $\left[{ }^{3} \mathrm{H}\right]$ tetrahydrofolate $(20-40 \mathrm{Ci} / \mathrm{mmol})$ was synthesized from $\left[{ }^{3} \mathrm{H}\right]$ folic acid as described (19).

Cell culture. Caco-2 cells (23, 24), MA104 cells (20), SV40 transformed human fibroblasts (25), and COS-1 (26) cells were grown as described.

Isolation of RNA. RNA was isolated from Caco-2 cells, using the guanidine thiocyanate/CsCl method (27). Polyadenylated RNA was selected by oligo-dT cellulose chromatography using standard methods (28).

Construction of the Caco-2 cDNA library. A cDNA library was constructed in $\lambda \mathrm{gt} 11$ according to a modification (28) of the method of Gubler and Hoffman (29) from $10 \mu \mathrm{g}$ of polyadenylated RNA isolated from Caco- 2 cells $10 \mathrm{~d}$ after confluence. The library contained 1.2 $\times 10^{6}$ independent clones and was amplified once.

Screening the cDNA library. Two oligonucleotide 'guessmer' probes (B5 and B6) were designed based on the published amino acid sequence of the human milk S-FBP (30). Ambiguous residues in the human sequence were assumed to be conserved in the bovine milk S-FBP sequence (31). B5 and B6 were 57 and 72 bases long, respectively. The cDNA library was screened in duplicate with ${ }^{32} \mathrm{P}$-labeled B5 and $\mathrm{B} 6$ to isolate a partial $\mathrm{CDNA}$ clone (designated $\mathrm{F} 4$ ). $\mathrm{F} 4$ was used to rescreen the library and five additional clones were isolated. The longest clone (designated $F 5$ ) was subcloned into Eco $R 1$ sites in pGEM4Z (pG4ZF56) and pCMV2 (pCMV2F53) (Fig. 1). The chimeric plasmids, pG4ZF56, pCMV2F53 were used to transform (32) Escherichia coli $\mathrm{DH}-1$ cells or $E$. coli TG-1 cells. DNA sequencing was performed according to the method of Sanger $(33,34)$ and is detailed in Fig. 2.

Nucleic acid blot hybridization. Poly A+ RNA from SV40 transformed human fibroblasts and total and poly A selected RNA from

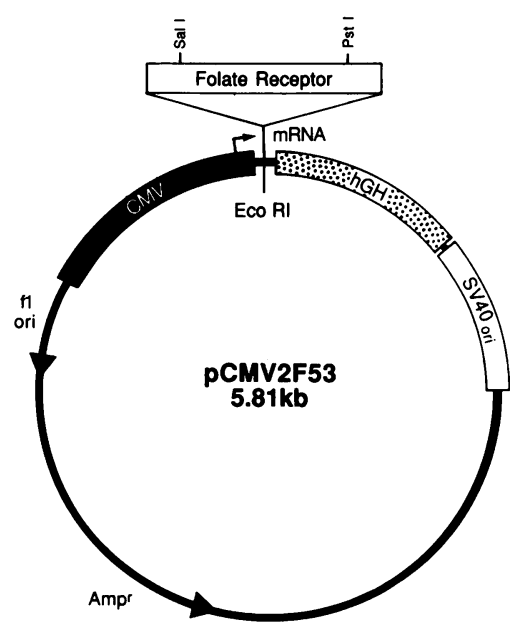

Figure 1. Expression vectors for transfection experiments. The expression vector pCMV2F53 was constructed by ligating the F5 Eco R1 fragment into the unique Eco R1 site of the PCMV2 polycloning site. Orientation was determined by Sal I and Pst I mapping as there are nonunique Sal I and Pst I sites in the polycloning site. pCMV2 has the $\mathrm{f} 1$ origin of replication, major immediate early region CMV promoter, a polycloning site, the $\mathrm{hGH}$ polyadenylation and transcription terminator, the SV40 early region promoter/enhancer and origin of replication and the plasmid pTZ18R (Pharmacia Fine Chemicals). pCMV2 alone and pCMV2F53 (shown here) were used in the transfection experiments.
Caco-2 cells were fractionated on $1 \%$ agarose gels containing $2.2 \mathrm{M}$ formaldehyde before capillary transfer to Nytran membranes and UV immobilization. The filters were preprehybridized in $0.15 \mathrm{M} \mathrm{NaCl}$, $0.015 \mathrm{M} \mathrm{Na}$ Citrate, $0.1 \% \mathrm{NaDodSO}_{4}$ at $65^{\circ} \mathrm{C}$ for $1 \mathrm{~h}$ and prehybridized in $50 \%$ formamide, $0.75 \mathrm{M} \mathrm{NaCl}, 50 \mathrm{mM} \mathrm{NaH} \mathrm{PO}_{4}, 10 \mathrm{mM}$ EDTA pH 7.4, $0.1 \% \mathrm{NaDodSO}_{4}$, and $200 \mu \mathrm{g} / \mathrm{ml}$ denatured salmon sperm DNA at $42^{\circ} \mathrm{C}$ for $1-2 \mathrm{~h} .20 \mathrm{ng}$ of the Eco R1 fragment from pG4ZF56 was labeled with ${ }^{32} \mathrm{P} \alpha$-dATP by random priming (35) and 20 $\times 10^{6} \mathrm{cpm}$ were added to the filters to hybridize. Hybridization was performed at $42^{\circ} \mathrm{C}$ in $50 \%$ formamide, $0.75 \mathrm{M} \mathrm{NaCl}, 50 \mathrm{mM}$ $\mathrm{NaH}_{2} \mathrm{PO}_{4}, 10$ mM EDTA pH 7.4, $2 \times$ Denhardt's solution, $0.1 \% \mathrm{Na}$ DodSO $_{4}, 100 \mu \mathrm{g} / \mathrm{ml}$ denatured salmon sperm DNA and $10 \%$ dextran sulfate (17-0340-01; Pharmacia Fine Chemicals) and washed at $68^{\circ} \mathrm{C}$ for $1 \mathrm{~h}$ in $0.15 \mathrm{M} \mathrm{NaCl}, 0.015 \mathrm{M} \mathrm{Na}$ Citrate, $0.1 \% \mathrm{NaDodSO}_{4}$, before autoradiography.

Transient expression of F5 in COS- 1 cells. $3 \times 10^{5}$ COS- 1 cells were seeded onto $100-\mathrm{mm}$ dishes $24 \mathrm{~h}$ before transfection. They were transfected with either no DNA (mock), $1 \mu \mathrm{g}$ of the expression vector pCMV2 having no insert, or pCMV2F53 with the folate receptor cDNA by the DEAE-Dextran method $(36,37)$. For the initial transfections, both indirect immunofluorescence (38) and assays for surface binding of 5 -methyl $\left[{ }^{3} \mathrm{H}\right]$ tetrahydrofolate were performed (20) (Table I). Additional transfections were performed to test for $\left[{ }^{3} \mathrm{H}\right]$ folic acid binding (Table I).

Purification of chicken antibodies. Serum containing antibodies against the M-FBP from human KB cells was kindly provided by Dr. J. F. Kolhouse (University of Colorado School of Medicine, Denver, $\mathrm{CO})$. Chicken immunoglobulins were obtained from the serum by $\mathrm{Na}_{2} \mathrm{SO}_{4}$ precipitation according to the method of Benedict (39). The purified IgG fraction was used at an antibody dilution of 1:250 in all fluorescent experiments.

Phosphatidylinositol-specific phospholipase C (PI-PLC) treatment of MA104 membranes. PI-PLC purified from Staphylococcus aureus was a gift from Dr. Martin G. Low (Columbia University College of Physicians and Surgeons, NY). Bacillus cereus PLC was obtained from Sigma (St. Louis, MO). MA 104 cells were cultured in T75 flasks for $5 \mathrm{~d}$ in folate-free media as previously described (20). Cells were rinsed once $(5 \mathrm{ml})$ with PBS and then incubated for $3 \mathrm{~h}$ at $37^{\circ} \mathrm{C}$ in folate-free medium containing $20 \mathrm{mM}$ Hepes ( $\mathrm{pH} 7.4)$ and $2 \mathrm{nM}\left[{ }^{3} \mathrm{H}\right]$ folic acid. The cells were rinsed once with PBS, harvested, lysed by freezing at $-80^{\circ} \mathrm{C}$ for $15 \mathrm{~min}$ in a hypotonic buffer $(20 \mathrm{mM}$ Tris, $\mathrm{pH} 8.0)$ containing $0.02 \mathrm{mg} / \mathrm{ml}$ leupeptin and $0.02 \mathrm{mg} / \mathrm{ml}$ aprotinin, and thawed at $4^{\circ} \mathrm{C}$. Cell extracts from three T-75 flasks were pooled and centrifuged at $100,000 \mathrm{~g}$ for $1 \mathrm{~h}$. The membrane pellet was resuspended in 20 $\mathrm{mM}$ Hepes ( $\mathrm{pH} 7.4$ ) and centrifuged at $100,000 \mathrm{~g}$ for $1 \mathrm{~h}$.

Table I. Binding of Radiolabeled Folates by COS-1 Cells

\begin{tabular}{llc}
\hline \multicolumn{1}{c}{ Condition } & \multicolumn{1}{c}{ Label } & Binding \\
\hline & & pmol/mg protein \\
pCMV2 & 5-methyl[ $\left.{ }^{3} \mathrm{H}\right]$ tetrahydrofolate & 0.70 \\
pCMV2F53 & 5-methyl[ $\left.{ }^{3} \mathrm{H}\right]$ tetrahydrofolate & 2.29 \\
pCMV2 & {$\left[{ }^{3} \mathrm{H}\right]$ folic acid } & 0.62 \\
pCMV2F53 & {$\left[{ }^{3} \mathrm{H}\right]$ folic acid } & 2.50 \\
\hline
\end{tabular}

The cells were transfected as detailed and binding of radiolabeled folate determined after the cells were washed with acid saline twice to remove endogenously bound folate. Experiments were done in duplicate and with a control for nonspecific binding (specific activity of the radiolabel reduced 100 -fold by simultaneous addition of unlabeled ligand). The values for nonspecific binding with 5-methyl $\left[{ }^{3} \mathrm{H}\right]$ tetrahydrofolate and $\left[{ }^{3} \mathrm{H}\right]$ folic acid were $\sim 0.1$ and 0.05 $\mathrm{pmol} / \mathrm{mg}$ protein, respectively. The results are the mean after subtraction of the nonspecific binding and are $\pm 10 \%$. 
The final pellet was resuspended in $20 \mathrm{mM}$ Hepes pH 7.4. Membranes were treated with PLC according a modification of the method of Roy-Choudhury et al. (40). $\left[{ }^{3} \mathrm{H}\right]$-labeled membranes $(48,000 \mathrm{cpm})$ were incubated with either no enzyme, $B$. cereus PLC $(12.5 \mathrm{U} / \mathrm{ml})$ or phosphatidylinositol-specific PLC $(24 \mu \mathrm{g} / \mathrm{ml})$ for $1 \mathrm{~h}$ at $37^{\circ} \mathrm{C}$ in a buffer containing $20 \mathrm{mM}$ Hepes (pH 7.4) and $0.1 \mathrm{mg} / \mathrm{ml}$ of folate-free BSA. Total volume of the assay was $1 \mathrm{ml}$. At the end of the incubation, the membrane suspensions were chilled to $4^{\circ} \mathrm{C}$ and immediately centrifuged at $100,000 \mathrm{~g}$ for $1 \mathrm{~h}$. A portion of the supernatant was counted. The remaining fraction was then treated with dextran-coated charcoal to remove any free $\left[{ }^{3} \mathrm{H}\right]$ folic acid $(20)$ and counted again.

\section{Results and Discussion}

Isolation of a cDNA for the human FBP. The strategy we used was to construct and screen a Caco-2 cDNA library with two different oligonucleotide 'guessmer' probes followed by screening with partial cDNA clones. A 991-bp clone (designated F5) coding for M-FBP was isolated and sequenced (Fig. 2).

Sequence characterization and comparison. The deduced sequence contains an open reading frame of 257 amino acids with a calculated $M_{\mathrm{r}} 28,256$. Compared with the human milk amino acid sequence, the deduced sequence is identical at 104

-95 GGAGAGCCACCTCCTCTCCCAGGAACTGAACCCAAA -60 -59 GGATCACCTGGTATTCCCTGAGAGTACAGATTTCTCCGGCGTGGCCCTCAAGGACAGAC ATGGCTCAGCGGATGACAACACAGCTGCTGCTCCTTCTAGTGTGGGTGGTGTAGTaGgG MetAl aGlnargivet ThrThrGl nLeuLeuLeuLeuLeuValTrpValAlaValValGly GAGGCTCAGACAMGGATTGCATGGGCAGGACTGAGCTTCTCAATGTCTGCATGAACGCC 21 GluAlaGInThrArg, I LALATrPAlaArgThrGLULeULeuAsnValCysMetAsnAla MAGCACCACMAGGAAAGCCAGGCCCGAGGACMGTTGCATGAGCAGTGTCGACCCTGG

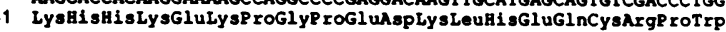
AGGMGGATGCCTGCTGTTCTACCAACACCAGCCAGGAGCCCATMGGATGTTTCCTAC 61 ArgLysAsnAl aCysCysSerThrAsnThrSerGInGluAlaHisLysAspValSerTyr CTATATAGATTCAACTGGMCCACTGTGGAGAGATGGCACCTGCCTGCAMACGGATTTC B1 LeuTy rArgPheAsnTrPAsnBISCysGlyGluHetAlaP rOAlaCysLysArghisPhe ATCCAGGACACCTGCCTCTACGAGTGCTCCCCCAACTTGGGGCCCTGGATCCAGCAGGTG 101 I leGlnAspThrCys LeuTyrGluCysSerP roAsnLeuGlyP roTrpI leGlnglnval GATCAGAGCTGGCGCAAGAGCGGGTACTGAACGTGCCCCTGTGCANAGAGGACTGTGAG 121 AspGInSerTrpArgLysGluArgValLeuAsnValP roLeuCysLysGluAspCysGLu CMATGGTGGGMGATTGTCGCACCTCCTACACCTGCAMGAGCAACTGGCACMAGGGCTGG 141 GInTrPTrPGIUAspCysArgThrSerTyrThrCysLysSerAsnTrPHisLysGlyTrp MACTGGACTTCAGGGTTTAACAAGTGCGCAGTGGGAGCTGCCTGCCAACCTTTCCATTTC 61 AsnTrpThrSerG1 yPheAsnLy SCYSAlaValG1 yAlaAl aCysGInP rOPhellisPhe TACTTCCCCACACCCACTGTTCTGTGCAMTGAMTCTGGACTCACTCCTACMAGGTCAGC 181 TyrPheP roThrP roThrValleuCysAsnGluIleTrpThrHis SerTyrLysValser MACTACAGCCGAGGGAGTGGCCGCTGCATCCAGATGTGGTTCGACCCAGCCCAGGGCAAC 201 AsnTyrSerArgGlySerGlyArgCysI leGInMet TrpPheAspP roAlaGInGIyAsn CCCAMTGAGGAGGTGGCGAGGTTCTATGCTGCAGCCATGAGTGGGGCTGGGCCCTGGGCA 221 ProAsnGluGluvalAlaArgPheTyrAlaAlaAlaMet SerGlyAlaGlyProT rpAla GCCTGGCCTTTCCTGCTTAGCCTGGCCCTMATGCTGCTGTGGCTGCTCAGCTGACCTCCT 241 AlaTrpP roPheLeuLeuSerLeuAlaLeuMet LeuLeuTrpLeuLeuSerEnd

ITIACCTTCTGATACCTGGAAATCCTTCCCCTGTTCAGCCCCACAGCTCCCAACTATTTG GTTCCTGCTCCATGGTCGGGCTCTGACAGCCACTTTGMATAMCCAGACACCGC 895

Figure 2. Nucleotide and deduced amino acid sequence of F5. The 991-bp Eco R1 fragment from clone F5 was subcloned into M13mp18 in both orientations and both strands were completely sequenced using universal and sequence specific primers. The $5^{\prime}$ untranslated region is numbered -95 to 0 . There is an in-frame stop codon at -42 . Nucleotide 1 is the $A$ of the initiator methionine residue 1 . The first residue of the mature protein is Ile 26 , which is six residues from the hydrophobic core of the postulated signal sequence (double underlined). Signal cleavage probably occurs between $\mathrm{Thr} 24$ and Arg 25 followed by proteolytic processing between Arg 25 and Ile 26 (arrow). The three consensus sites for $N$-linked glycosylation sites are marked with an asterisk ( $\left.{ }^{*}\right)$. The $3^{\prime}$ untranslated region contains a consensus polyadenylation signal (single underline). of the 105 residues (30) (Fig. 3). Likewise, the alignment comparison of the bovine milk with the deduced sequence from F5 ending with alanine 230 shows that 172 out of 210 amino acids are identical (Fig. 3). The protein contains 16 cysteine residues that apparently form eight disulfide bonds (31) and three consensus sites (ASN-X-SER/THR) for $N$-linked glycosylation.

Analysis of FBP $m R N A$. Northern blotting was performed on $5 \mu \mathrm{g}$ each of poly A+ RNA from SV40-transformed human fibroblasts (Fig. $4 \mathrm{~A}$ ) and total (Fig. $4 \mathrm{~B}$ ) and poly A (Fig. $4 \mathrm{C}$ ) RNA from Caco- 2 cells. SV40 transformed human fibroblasts were chosen because they do not express detectable M-FBP as measured by $\left[{ }^{3} \mathrm{H}\right]$ folic acid binding (data not shown). The FBP cDNA probe (F5) hybridized to a discrete mRNA band of 1.1 kb (Fig. 4, lanes $B$ and $C$ ), whereas there was no signal in the SV40 transformed fibroblast lane $(A)$ even after overexposure. The blot was stripped and reprobed with an actin probe confirming that lanes $A$ and $C$ had comparable amounts of poly A+ RNA (data not shown).

The FBP contains a cleaved hydrophobic amino-terminal signal sequence. The nucleotide sequence of the cDNA for the FBP and the predicted amino acid sequence are shown in Fig. 2. Taking the first ATG as the start site, the first 20 amino acids have the characteristics of a typical signal sequence for endoplasmic reticulum translocation $(41,42)$. We predict that signal cleavage is between $\operatorname{Thr} 24$ and $\operatorname{Arg} 25$ because this site has a favorable von Heijne (43) score (6.7), it is five residues downstream of the hydrophobic core, and the von Heijne score for cleavage between $\mathrm{Arg}_{25}$ and $\mathrm{Ile}_{26}$ is extremely unfavorable (-9.9). This would require that a second proteolytic processing event occur subsequent to signal cleavage because the amino acid sequence of the mature protein begins with Ile 26 (Fig. 2).

Transient expression of FBP cDNA in COS-1 cells. We performed transfections of COS-1 cells with no DNA (mock), the expression vector pCMV2 alone (negative control) and the F5 cDNA subcloned into pCMV2 (pCMV2F53). In the initial transfection, we performed indirect immunofluorescence (Fig. 5 ) in addition to 5-methyl $\left[{ }^{3} \mathrm{H}\right]$ tetrahydrofolate binding assays (Table I). Mock and pCMV2 transfected cells had a low level of immunofluorescence staining. Approximately $6 \%$ of the cells that were transfected with pCMV2F53, however, were brightly fluorescent (Fig. 5). Cells transfected with pCMV2F53 had the same staining pattern as the mock and pCMV2 transfected cells but the staining was much more intense. In the same transfection, 5-methyl $\left[{ }^{3} \mathrm{H}\right]$ tetrahydrofolate binding increased 3.3-fold. Because only $6 \%$ of the cells expressed the cDNA, as judged by immunofluorescence, we estimate that folate binding activity was increased $\sim 55$-fold per transfected cell over basal expression. Similar levels of $\left[{ }^{3} \mathrm{H}\right]$ folic binding were demonstrated in subsequent transfections (Table I).

Carboxyl terminus of the FBP contains a signal for GPI linkage. The only hydrophobic domain, other than the cleaved signal, of sufficient length to span the membrane is the COOH-terminal 19 residues. There are no charged residues flanking this domain and no putative cytoplasmic tail. A search of known protein sequences revealed no transmembrane proteins lacking cytoplasmic tails. A comparison of the bovine sequence with the deduced sequence (Fig. 3) in the carboxyl-terminal region of the molecule shows that the cDNA predicts 14 hydrophobic residues with no counterpart in the mature bovine protein. The posttranslational removal of just such a hydrophobic sequence at the carboxyl end of a 


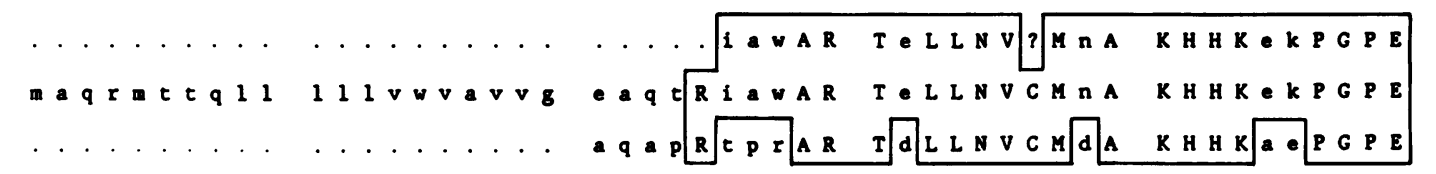

Humen Mink

Clone F5

Bovine Millk

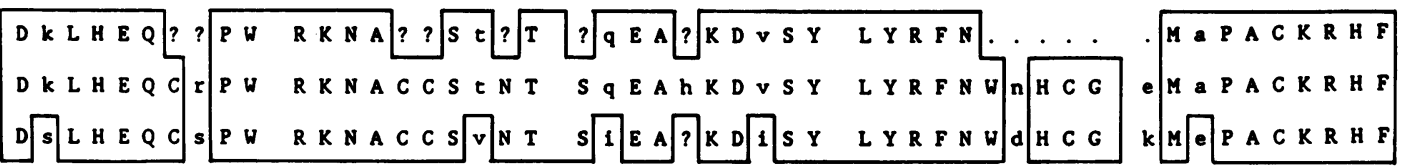

Human Mik

Clone F5

Bovine Milk

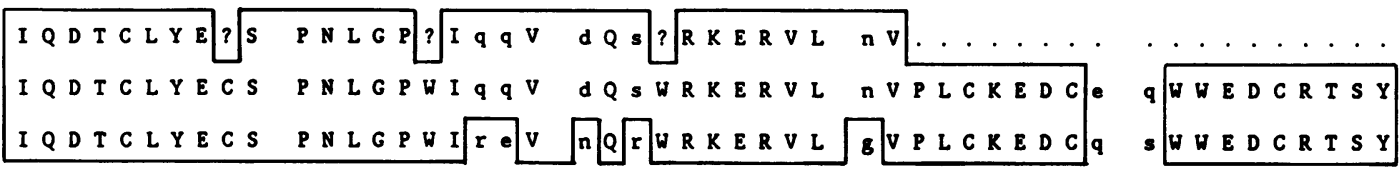

Human Milk

Clone F5

Bovine Milk

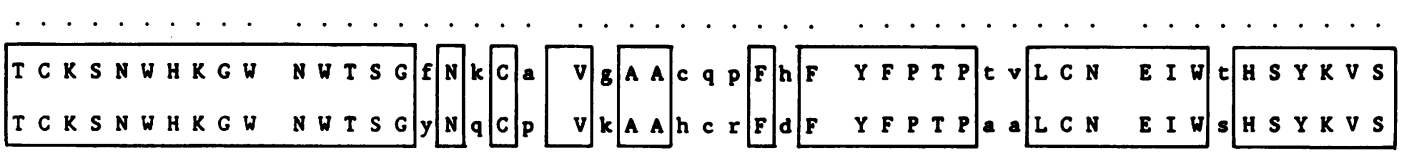

Human Mik

Clone F5

Bovine Milk

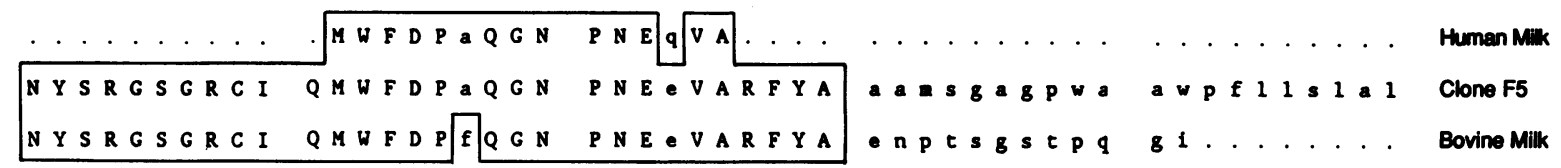

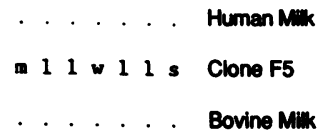

Figure 3. Sequence comparison. Alignment of the partial amino acid sequence of human milk S-FBP, the deduced amino acid sequence from F5 and bovine milk S-FBP amino acid sequence is shown. Identical residues are enclosed in boxes and positions where two of the three sequences are identical are lower case and boxed.

membrane protein is characteristic of proteins that are retained in the membrane by a GPI anchor.

A standard test for identifying a GPI anchored membrane protein is to determine if it is released from membranes by

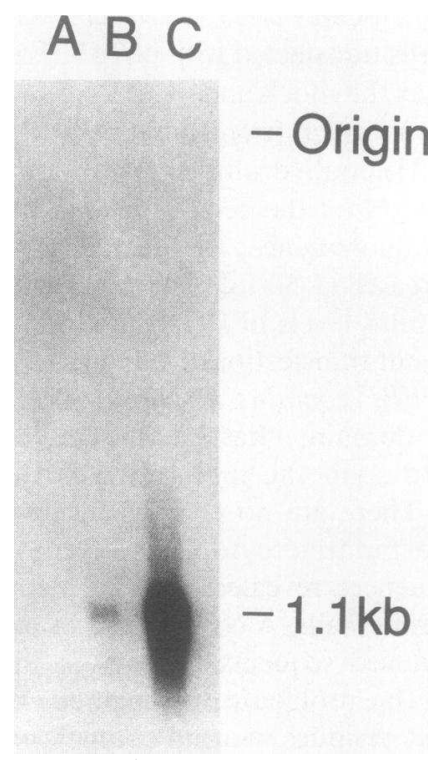

Figure 4. RNA blot analysis. Each lane contained $5 \mu \mathrm{g}$ of the stated RNA. Lane $A$, poly A+ RNA from SV40-transformed human fibroblasts; lane $B$, total RNA from Caco- 2 cells; lane $C$, poly $A+$ RNA from Caco- 2 cells. The blot was probed with ${ }^{32} \mathrm{P} \alpha$ dATP labeled F5 cDNA, washed stringently and autoradiographed for $4 \mathrm{~h}$. A single band was identified at $1.1 \mathrm{~kb}$ in lanes $B$ and $C$. 24-h exposure failed to demonstrate any signal in lane $A$.

PI-PLC (44, 45). Folate depleted MA104 cells were labelled with $\left[{ }^{3} \mathrm{H}\right]$ folic acid, a high-affinity folate that does not dissociate from the M-FBP (20). Membranes were prepared, which contained all of the bound $\left[{ }^{3} \mathrm{H}\right]$ folic acid, and incubated with either no enzyme, $B$. cereus PLC which contains trace amounts of PI-PLC, or PI-PLC. As shown in Table II, only 6\% of the radioactivity was released in the absence of enzyme. By contrast, $B$. cereus PLC released $15 \%$ of the radioactivity and PI-PLC released $76 \%$ of the radioactivity. When the PI-PLC supernatant was chromatographed on a G-100 Sephadex column, all of the radioactivity eluted with an approximate molecular weight of 40,000 (data not shown).

Difference between the membrane and soluble FBPs.

Cleavage of the GPI linkage may explain how the S-FBP is generated from the M-FBP. Both alkaline phosphatase $(44,45)$ and variable surface glycoprotein of trypanosomes $(44,45)$ are GPI-linked membrane proteins that are released in response to various stimuli by specific phospholipase digestion. Because phospholipase D specific for the PI anchor is abundant in plasma (46), this enzyme may play a role in releasing M-FBP from the surface of cells that express the protein.

An alternative hypothesis is that there are separate mRNAs for the two forms of FBP that are generated either by alternative RNA splicing from a single gene or by transcription from two separate genes. Northern analysis detected only one RNA species in tissue culture cells; however, this method can not 

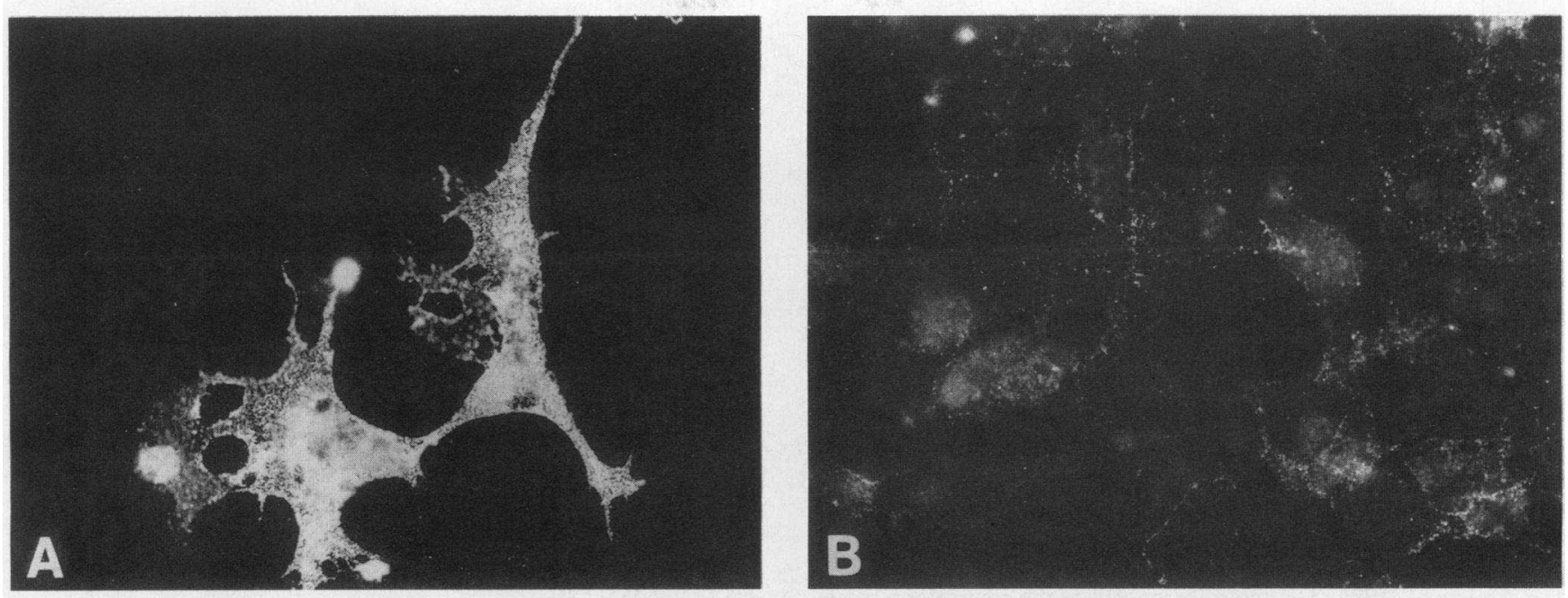

Figure 5. Indirect immunofluorescence staining of COS-1 cells transfected with either pCMV2F53 $(A)$ or pCMV2 (B). COS-1 cells were grown for $2 \mathrm{~d}$ before transfection. After $40 \mathrm{~h}$ of further growth, the cells were chilled to $4^{\circ} \mathrm{C}$ and incubated with a 1:250 dilution of anti-FBP IgG for 1 $\mathrm{h}$ at $4^{\circ} \mathrm{C}$. The cells were washed, fixed, and processed to localize sites of antibody binding as described. Both fields contain the same number of cells but the contrast had to be adjusted in $A$ because of the fluorescence intensity of the cells.

distinguish between RNAs that differ by fewer than 50 nucleotides.

The cDNA for the FBP codes for a membrane protein that has the characteristics of a membrane protein anchored by a GPI linkage. Immunofluorescence images (Fig. 5) indicate that the protein is located in discrete sites on the membrane. Moreover, there is good biochemical evidence that this protein cyclically enters the cell and returns to the surface (20). Recently, van der Bosch et al. (47) reported that 5'-nucleotidase, another surface membrane protein that is anchored by GPI (48), recycles in hepatoma cells with similar kinetics to M-FBP. Future analysis of M-FBP should provide new insights into how internalization and recycling of the folate receptor is related the delivery of folate to the cytoplasm of cells.

Table II. Release of Receptor $\left[{ }^{3} \mathrm{H}\right]$-Folic Acid Complex by PI-PLC

\begin{tabular}{lcr}
\hline & \multicolumn{2}{c}{$\begin{array}{c}\% \text { total }\left[{ }^{3} \mathrm{H}\right] \text { folic acid } \\
\text { in supernatant }\end{array}$} \\
\cline { 2 - 3 } \multicolumn{1}{c}{ Condition } & -Charcoal & +Charcoal \\
\hline Control (no incubation) & - & 2.0 \\
Control (incubation/no enzyme) & 10.8 & 5.4 \\
PLC (B. cereus nonspecific) & 21.2 & 14.6 \\
PI-PLC (GPI specific) & 88.1 & 76.4 \\
& & \\
\hline
\end{tabular}

MA104 cells were grown for $3 \mathrm{~d}$ in low folate medium and then incubated $3 \mathrm{~h}$ at $37^{\circ} \mathrm{C}$ in the presence of $2 \mathrm{nM}\left[{ }^{3} \mathrm{H}\right]$ folic acid. $\left[{ }^{3} \mathrm{H}\right]$-labeled membranes were prepared using the freeze-thaw method. To test for the effects of PI-PLC, the labeled membranes were treated under the conditions noted in the first column and centrifuged at $100,000 \mathrm{~g}$. Aliquots of the supernatant were counted (-charcoal) or first treated with dextran-coated charcoal to remove free folate (+charcoal) and counted. The results are the mean of duplicate experiments and are $\pm 5 \%$ in samples containing enzymes. Each reaction contained $\sim 50,000 \mathrm{cpm}\left[{ }^{3} \mathrm{H}\right]$ folic acid.

\section{Acknowledgments}

The construction of the Caco-2 cDNA library and the cloning of the cDNA encoding folate binding protein was carried out in the laboratory of Joe Sambrook and Mary-Jane Gething, whom we thank for financial support and scientific advice.

This work was also supported by National Institutes of Health grant 1K11DK-0186001 and ACS CH-228. J. M. Sanders is a fellow of the King Foundation and B. A. Kamen is a Burroughs-Wellcome Scholar in Pharmacology.

\section{References}

1. Salter, D. N., J. E. Ford, K. J. Scott, and P. Andrews. 1972. Isolation of the folate-binding protein from cow's milk by the use of affinity chromatography. FEBS (Fed. Eur. Biochem. Soc.) Lett. 20:302-306.

2. Salter, D. N., K. J. Scott, H. Slade, and P. Andrews. 1981. The preparation and properties of folate-binding protein from cow's milk. Biochem. J. 193:469-476.

3. Svendsen, I., B. Martin, T. G. Pedersen, S. I. Hansen, J. Holm, and J. Lyngbye. 1979. Isolation and characterization of the folatebinding protein from cow's milk. Carlsberg Res. Commun. 44:89-99.

4. Waxman, S., and C. Schreiber. 1973. Characteristics of folic acid-binding protein in folate-deficient serum. Blood. 42:291-301.

5. Kamen, B. A., and J. D. Caston. 1975. Purification of folate binding factor in normal umbilical cord serum. Proc. Natl. Acad. Sci. USA. 72:4261-4264.

6. Waxman, S., and C. Schreiber. 1975. The purification and characterization of the low molecular weight human folate binding protein using affinity chromatography. Biochemistry. 14:5422-5428.

7. Rubinoff, M., C. Schreiber, and S. Waxman. 1977. The isolation and characterization of the folate binding protein from goat milk. FEBS (Fed. Eur. Biochem. Soc.) Lett. 75:244-248.

8. Hansen, S. I., J. Holm, and J. Lyngbye. 1980. High-affinity protein binding of folate in urine. IRCS (Int. Res. Commun. Sys.) Med. Sci. Lib. Compend. 8:846-847.

9. Fischer, C. D., M. da Costa, and S. P. Rothenberg. 1975. The heterogeneity and properties of folate binding proteins from chronic myelogenous leukemia. Blood. 46:855-867. 
10. Rothenberg, S. P. 1970. A macromolecular factor in some leukemic cells which binds folic acid. Proc. Soc. Exp. Biol. Med. 133:428-432.

11. Antony, A. C., C. S. Utley, P. D. Marcell, and J. F. Kolhouse. 1982. Isolation, characterization, and comparison of the solubilized particulate and soluble folate binding proteins from human milk. $J$. Biol. Chem. 257:10081-10089.

12. Selhub, J., and W. Franklin. 1984. The folate-binding protein of rat kidney. Purification, proterties, and cellular distribution. J. Biol. Chem. 259:6601-6606.

13. Antony, A. C., C. Utley, K. C. Van Horne, and J. F. Kolhouse. 1981. Isolation and characterization of a folate receptor from human placenta. J. Biol. Chem. 256:9684-9692.

14. Antony, A. C., M. A. Kane, R. M. Portillo, P. C. Elwood, and J. F. Kolhouse. 1985. Studies of the role of a particulate folate-binding protein in the uptake of 5-methyltetrahydrofolate by cultured human KB cells. J. Biol. Chem. 260:14911-14917.

15. Kane, M. A., P. C. Elwood, R. M. Portillo, A. C. Antony, and J. F. Kolhouse. 1986. The interrelationship of the soluble and membrane-associated folate binding proteins in human $\mathrm{KB}$ cells. J. Biol. Chem. 261:15625-15631.

16. Rubinoff, M., R. Abramson, C. Schreiber, and S. Waxman. 1981. Effect of a folate-binding protein on the plasma transport and tissue distribution of folic acid. Acta Haematol (Basel). 63:145-152.

17. Tani, M., T. Fushiki, and K. Iwai. 1983. Influence of folatebinding protein from bovine milk on the absorption of folate in gastrointestinal tract of rat. Biochim. Biophys. Acta. 757:274-281.

18. Tani, M., and K. Iwai. 1984. Some nutritional effects of folatebinding protein in bovine milk on the bioavailability of folate to rats. Am. J. Nutr. 114:778-785.

19. Kamen, B. A., and A. Capdevila. 1986. Receptor-mediated folate accumulation is regulated by the cellular folate content. Proc. Natl. Acad. Sci. USA. 83:5983-5987.

20. Kamen, B. A., M.-T. Wang, A. J. Streckfuss, X. Peryea, and R. G. W. Anderson. 1988. Delivery of folates to the cytoplasm of MA 104 cells is mediated by a surface membrane receptor that recycles. J. Biol. Chem. 263:13602-13609.

21. Luhrs, C. A., P. Pitiranggon, M. da Costa, S. P. Rothenberg, B. L. Slomiany, L. Brink, G. I. Tous, and S. Stein. 1987. Purified membrane and soluble folate binding proteins from cultured $\mathrm{KB}$ cells have similar amino acid compositions and molecular weights but differ in fatty acylation. Proc. Natl. Acad. Sci. USA. 84:6546-6549.

22. Thomsen, D. R., R. M. Stenberg, W. F. Goins, and M. F. Stinski, 1984. Promoter-regulatory region of the major immediate early gene of human cytomegalovirus. Proc. Natl. Acad. Sci. USA. 81:659-663.

23. Pinto, M., S. Robine-Leon, M.-D. Appay, M. Kedinger, N. Triadou, E. Dussaulx, B. Lacroix, P. Simon-Assmann, K. Haffen, J. Fogh, and A. Zweibaum. 1983. Enterocyte-like differentiation and polarization of the human colon carcinoma cell line Caco-2 in culture. Biol. Cell. 47:323-330.

24. Hauri, H-P., E. E. Sterchi, D. Bienz, J. A. M. Fransen, and A. Marxer. 1985. Expression and intracellular transport of microvillus membrane hydrolases in human intestinal epithelial cells. J. Cell Biol. 101:838-851.

25. Moore, M. S., and R. G. W. Anderson. 1989. Towards an in vitro system for studying clathrin coated pit function. J. Cell. Sci. In press.

26. Gluzman, Y. 1981. SV 40-transformed simian cells support the replication of early SV 40 mutants. Cell. 23:175-182.

27. Chirgwin, J. M., A. E. Przybyla, R. J. MacDonald, and W. J. Rutter. 1979. Biochemistry. 18:5294-5299.
28. Sambrook, J., E. F. Fritsch, and T. Maniatis. 1989. Molecular Cloning: A Laboratory Manual. Cold Spring Harbor Laboratory, Cold Spring Harbor, NY. 545 pp.

29. Gubler, U., and B. J. Hoffman. 1983. A simple and very efficient method for generating cDNA libraries. Gene (Amst.). 25:263269.

30. Svendsen, I., S. I. Hansen, J. Holm, and J. Lyngbye. 1982. Amino acid sequence homology between human and bovine low molecular weight folate binding protein isolated from milk. Carlsberg Res. Commun. 47:371-376.

31. Svendsen, I., S. I. Hansen, J. Holm, and J. Lyngbye. 1984. The complete amino acid sequence of the folate-binding protein from cow's milk. Carlsberg Res. Commun. 49:123-131.

32. Hanahan, D. 1985. Techniques for transformation of E. coli. In DNA Cloning: A Practical Approach. Vol. I. D. M. Glover, editor. IRL Press, Oxford, UK. 109-135.

33. Sanger, F., S. Nicklen, and A. R. Coulson. 1977. DNA sequencing with chain-terminating inhibitors. Proc. Natl. Acad. Sci. USA. 74:5463-5467.

34. Chen, E. Y., and P. H. Seeburg. 1985. Laboratory methods supercoil sequencing: a fast and simple method for sequencing plasmid DNA. DNA (NY). 4:165-170.

35. Feinberg, A. P., and B. Vogelstein. 1983. A technique for radiolabeling DNA restriction endonuclease fragments to high specific activity. Anal. Biochem. 132:6-13.

36. Gorman, C. 1985. High efficiency gene transfer into mammalian cells. In DNA Cloning: A Practical Approach. Vol. II. D. M. Glover, editor. IRL Press, Oxford, UK. 143-190.

37. Bird, P., M.-J. Gething, and J. Sambrook. 1987. Translocation in yeast and mammalian cells: not all signal sequences are functionally equivalent. J. Cell. Biol. 105:2905-2914.

38. Anderson, R. G. W. 1986. Methods for visualization of the LDL pathway in cultured human fibroblasts. Methods Enzymol. 129:201-215.

39. Benedict, A. B. 1967. Production and purification of chicken immunoglobulins. In Methods in Immunology and Immunochemistry. C. A. Williams and M. W. Chase, editors. Academic Press, NY. 229-237.

40. Roy-Choudhury, S., V. S. Mishra, M. G. Low, and M. Das. 1988. A phospholipid is the membrane-anchoring domain of a protein growth factor of molecular mass $34 \mathrm{kDa}$ in placental trophoblasts. Proc. Natl. Acad. Sci. USA. 85:2014-2018.

41. von Heijne, G. 1985. Signal sequences. The limits of variation. J. Mol. Biol. 184:99-105.

42. von Heijne, G. 1984. How signal sequences maintain cleavage specificity. J. Mol. Biol. 173:243-251.

43. von Heijne, G. 1986. A new method for predicting signal sequence cleavage sites. Nucleic Acids. Res. 14:4683-4690.

44. Low, M. G. 1987. Biochemistry of the glycosyl-phosphatidylinositol membrane protein anchors. Biochem. J. 244:1-13.

45. Ferguson, M. A. J., and A. Williams. 1988. Cell-surface anchoring of proteins via glycosyl-phosphatidylinositol structures. Annu. Rev. Biochem. 57:285-320.

46. Davitz, M. A., D. Hereld, S. Shak, J. Krakow, P. T. Englund, and V. Nussenzweig. 1987. A glycan-phosphatidylinositol-specific phospholipase D in human serum. Science (Wash. DC). 238:81-84.

47. van den Bosch, R. A., A. P. M. du Maine, H. J. Geuze, A. van der Ende and G. J. Strous. 1988. Recycling of $5^{\prime}$ nucleotidase in a rat hepatoma cell line. EMBO (Eur. Mol. Biol. Organ.) J. 7:3345-3351.

48. Shukla, S. D., R. Coleman, J. B. Finean, and R. H. Michell. 1980. Selective release of plasma-membrane enzymes from rat hepatocytes by a phosphatidylinositol-specific phospholipase C. Biochem. J. 187:277-280. 